\title{
Perception of Farmers towards APMC Markets in Raichur District of Karnataka, India
}

\author{
M. N. Chandan ${ }^{1}$, K. K. Shashidhara ${ }^{2 *}$, B. S. Reddy ${ }^{3}$ and S. B. Goudappa ${ }^{1}$ \\ ${ }^{1}$ Department of Agricultural Extension Education, UAS, Raichur, 584104 \\ ${ }^{2}$ Department of Agricultural Extension Education, College of Agriculture, Bheemaryangudi, \\ UAS, Raichur, 585 287, India \\ ${ }^{3}$ Dept. of Agricultural Economics, Agricultural Extension Education Centre, \\ Bheemaryangudi, UAS, Raichur, 585287 \\ *Corresponding author
}

\begin{tabular}{|l|}
\hline K e y w o r d s \\
Extension activities, \\
$\begin{array}{l}\text { Farmers, Role } \\
\text { perception }\end{array}$ \\
\hline Article Info \\
\hline $\begin{array}{l}\text { Accepted: } \\
\text { 22 June } 2020 \\
\text { Available Online: } \\
\text { 10 July } 2020\end{array}$ \\
\hline
\end{tabular}

\section{A B S T R A C T}

The study analyzed the perception of farmers towards APMC markets in Raichur district of Karnataka. Four taluks of district were selected. Thirty farmers from each selected taluka APMC markets were selected randomly, constituting 120 farmers for the study. The 'Ex-post facto' design was employed for the study. The study revealed that more than half $(52.50 \%)$ of the respondents belonged to middle age followed by old age $(27.50 \%)$ and young age group $(20.00 \%)$. Further, 41.67 per cent of farmers had high marketable surplus followed by 33.33 and 25.00 per cent of medium and low marketable surplus respectively. Similarly, 44.17 per cent had high marketed surplus followed by 28.33 and 27.50 per cent of medium and high marketed surplus. More than fifty per cent of the respondents $(53.33 \%)$ had moderately perceived their roles about extension activities of APMC markets followed by 28.33 per cent had lower level and 18.33 per cent. About 60.00 per cent of farmers had perceived about the role "ensuring transparency in trading that takes place in market area' and 40.00 per cent of them had not perceived about the role of APMC market. Regarding the role 'ensuring immediate payment to farmers' 67.50 per cent had perceived and 32.50 per cent had not perceived about the role.

\section{Introduction}

Agriculture is the largest sector in the Indian economy and it is having a crucial role to play in the country's economic development by providing food and raw materials, employment to large proportion of population, capital for its own development and surpluses for national economic development. Agriculture accounts for about 
18 per cent of GDP and still about two third of working population mainly depend upon this sector for their livelihood (Joshi, 2014).

Market is said to be a regulated market when the State Government establishes a market under a specific enactment and frames rules and regulations to conduct business therein (Singh, 1993). When the State or any Public Authority comes forward to enforce regulation for the organization of market, it is termed as a Regulated Market.

The present agricultural scenario poses a threat to the marginal and small farmers of India. These farmers could cope up with this vulnerable situation, only if they undertake agricultural activities keeping the market in view. The farmers need to be brought out of their traditional fanning habits to modern market-oriented farming by taking care of quality productivity and market needs. Fanners will need to reorient their cropping pattern as per the market demand, changing technology, economic reforms, consumer awareness and new export-import policies for agricultural commodities.

The farmers need to be exposed to the actual needs of consumers and prepare them for producing such products in desirable forms. The services of marketing extension should relate to the motivation for demand driven production, comparative advantages of the existing marketing channels, functional merits of marketing system and price advantage. The APMC being an institution comprising of farmers representatives, traders and government departments, can organize various extension education activities successfully.

The APMC's infrastructure and resources will be best utilized by performing the complementary role of agricultural marketing extension. The APMC's are normally located at block and district level, so technical support to them for carrying out extension function can be ensured by establishing strong linkages with the development departments, Panchayat raj institutions, NGO's and private organizations in their jurisdiction. Participation of APMCs in agricultural marketing extension work will strengthen the extension system in the States.

\section{Material and Methods}

The research study on role perception of farmers towards extension activities of APMCs in Raichur district of Karnataka was conducted during the year 2018-19. The study was conducted purposively in Raichur district. Major APMCs of Raichur district Raichur, Lingasugur, Manvi, Sindhanur were selected from each talukas. The data as collected from 120 farmers from four APMC's using ex-post-facto design. Schedule was developed to measure the role perception. The scale consists of 14 roles. The response for each item was scored 1 for perceived and for not perceived response the zero score was given. The total score of the respondent on the scale was obtained by summing up the scores of all the statements in the scale. The higher score indicates that respondent had high role perception and vice versa.

\section{Results and Discussion}

Table 1 data depicts that, 53.33 per cent of the respondents had moderately perceived their roles about extension activities of APMC market followed by 28.33per cent had lower level and 18.33per cent had higher level of role perception about extension activities of APMC market.

About 60.00 per cent of farmers had perceived about the role 'ensuring transparency in trading that takes place in market area' and 40.00 per cent of them had 
not perceived about the role of APMC market (Table 2). Regarding the role 'ensuring immediate payment to farmers' 67.50 per cent had perceived and 32.50 per cent had not perceived about the role. Majority of the farmers felt that APMC should ensure transparency in trading so that they can indulge in fair transactions. Transparency in trading activities was felt essential as it would enable better marketing practices by which everyone was benefitted and no one was cheated. Immediate payment should be given to the farmers for their produce without much delay. Timely Immediate payment makes farmers balance their day to day monetary needs and also they won't be under stress of debt.

Regarding the role 'to prevent malpractices by the traders', 61.66 per cent of farmers had perceived and 38.34 per cent had not perceived about the role. Half of the farmers $(50.83 \%)$ had perceived about the role dissemination of market information on arrivals and prices of agricultural produce' and 49.17 per cent had not perceived about the role. The farmers perceived that it is important to prevent malpractices by traders so that they can get fair and remunerative price for their produce. Farmers suffer losses if traders indulge in malpractices. Market information regarding arrivals and price of the commodities is very essential for the farmers by which the farmers can decide when and where to sell the produce. It is therefore the duty of the APMC to make farmers aware of the market information. About 68.33 per cent had not perceived about the role 'ensuring grading of agricultural produce' and 31.67 had perceived about the role. Regarding 'providing infrastructure facilities in the market' 57.50 per cent had not perceived and 42.50 per cent had perceived about the role.

Post harvest practices play an important role in enhancing the price of commodity, practices like grading which separate the produce based on required specifications helps to obtain better price for the produce. For good marketing practices it is essential to provide adequate market infrastructure. The facilities in the market determine the quantity and magnitude of marketing activities, physical facilities such as loading and unloading areas, internal roads and storage facilities and other basic amenities have to be provided.

About 70.83 per cent of farmers had perceived and 29.17 per cent of farmers had not perceived about the role 'providing advisory services through mass media'. Regarding the role 'providing facilities for storage of farm produce' 54.16 per cent had perceived and 45.84 per cent had not perceived about the role.

Advisory services like crop production according to market demand, avoiding post harvest losses, maintaining high quality of farm produce etc. should be provided for better marketing activities. Mass media can be used as an effective tool for dissemination of advisory information on a widespread basis covering more number of farmers. There is reduction in quality and quantity of the produce due to climate logical factors such as heavy rainfall, drought etc. increased pest and disease attack as a result of favourable climate leads to crop loss. Once the crop is harvested it needs to be stored properly to prevent from deterioration. It is therefore very essential to provide good storage facilities for the produce so that it can prevent distress sale and farmers can market it when there is good price.

Regarding the role 'ensuring remunerative price for agriculture produce' 64.16 per cent had perceived and 35.84 per cent had not perceived. More than half of the farmers $(52.50 \%)$ had perceived about the role 'create awareness about government schemes on 
marketing of agriculture produce' and 47.50 per cent had not perceived. Remunerative price should be ensured for the farmers and in case of adverse climatic conditions or crop failure minimum support price should be provided so that farmers can get minimal income. The APMC must ensure fair and remunerative prices for the benefit of the farmers. The APMC should communicate government schemes regarding marketing to farmers where they can avail the benefits from the government like getting inputs at subsidized rates or availing credit facilities.

About 75.00 per cent of farmers had perceived and 25.00 per cent of farmers had not perceived about the role 'ensure correct weighment and packing of agriculture produce'. Regarding the role 'linking of credit with marketing of farm produce' 65.83 per cent of farmers had not perceived and 34.17 per cent had perceived about the role. Accurate weighing is important for the farmers because if there is any malpractices in weighing farmers suffer losses so more number of farmers is aware about weighing activities.

Majority of the farmers are small and medium farmers when they are in need of money they pledge the produce and get money to meet their personal requirements. Regarding the role "prevention of unauthorized deduction by commission agents during the sale of produce' 78.33 per cent of farmers had perceived and 21.67 per cent had not perceived about the role. About 72.50 per cent of farmers had perceived and 27.50 had not perceived about the role 'illegal deduction of commission by commission agents'.

APMC must ensure fair practices by traders, commission agents so that farmers are not under loss, there is a possibility of loss of produce at the time of sampling and assessment and such losses must be minimized as much as possible. Illegal and high deduction of commission by the agents must be controlled. Only regulated amount of commission should be collected from the farmers and must not be overburdened with illegal commission practices.

The profile characteristics of respondents are presented in Table 3 that more than half $(52.50 \%)$ of the respondents belonged to middle age followed by old age $(27.50 \%)$ and young age group (20.00\%). This is because the middle-aged beneficiaries might be more interested, eager and enthusiastic in trying out new things than younger and old aged. The younger generation are not attracted to agriculture and are moving out of village that may be contributes to less respondents in young age group. The educational status of the respondents revealed that $(30.41 \%)$ of the farmers had education up to high school followed by pre-university $(20.83 \%)$, primary school (14.60 \%), graduation (14.16\%), illiterates $(12.50 \%)$ and middle school (7.50 $\%)$. Non-realization of the influence of formal education in one's life, illiteracy of the parents might have come in the way of getting better education by their parents. With respect to land holding, more than one third (36.50 $\%)$ of the respondents belonged to small farmers category followed by semi-medium (34.60\%), medium (16.50\%), marginal (9.10 $\%$ ) and 3.30 per cent of respondents are large farmers. This might be due to splitting of joint families the land is being fragmented and large farms are converted into small size farms. With regards to farming experience in agriculture, 36.66 per cent of respondents belonged to medium farming experience category followed by 35.00 per cent and 28.34 per cent of low and high level of farming experience. This might be because of predominant age groups of the respondents. In case of cropping pattern half of the farmers (50.00\%) practiced double cropping pattern followed by mono cropping $(26.66 \%)$ and mixed cropping $(23.34 \%)$. 
Table.1 Distribution of farmers according to their role perception about extension activities of APMC markets

\begin{tabular}{|c|l|c|c|}
\hline \multicolumn{1}{|c|}{ Sl. No. } & \multicolumn{1}{|c|}{ Perception } & Frequency & Per cent \\
\hline $\mathbf{1}$ & Low $(\leq 8.04)$ & 34 & 28.33 \\
\hline $\mathbf{2}$ & Medium $(8.05-9.51)$ & 64 & 53.34 \\
\hline $\mathbf{3}$ & High $(\geq 9.52)$ & 22 & 18.33 \\
\hline & & Mean $=\mathbf{8 . 7 8}$ & SD $=\mathbf{1 . 7 5}$ \\
\hline
\end{tabular}

Table.2 Distribution of farmers according to their specific role perception about extension activities of APMC market

\begin{tabular}{|c|c|c|c|c|c|}
\hline \multirow[t]{2}{*}{ Sl. No. } & \multirow[t]{2}{*}{ Perception } & \multicolumn{2}{|c|}{ Perceived } & \multicolumn{2}{|c|}{$\begin{array}{c}\mathrm{n}=120 \\
\text { Not Perceived }\end{array}$} \\
\hline & & $\mathbf{F}$ & $\%$ & $\mathbf{F}$ & $\%$ \\
\hline 1 & $\begin{array}{l}\text { Ensuring transparency in trading that takes place } \\
\text { in market area. }\end{array}$ & 72 & 60.00 & 48 & 40.00 \\
\hline 2 & Ensuring immediate payment to farmers & 81 & 67.50 & 39 & 32.50 \\
\hline 3 & To prevent malpractices by the traders & 74 & 61.66 & 46 & 38.34 \\
\hline 4 & $\begin{array}{l}\text { Dissemination of market information on arrivals } \\
\text { and prices of agricultural produce }\end{array}$ & 59 & 49.17 & 61 & 50.83 \\
\hline 5 & Ensuring grading of agricultural produce & 38 & 31.67 & 82 & 68.33 \\
\hline 6 & Providing infrastructure facilities in the market & 51 & 42.50 & 69 & 57.50 \\
\hline 7 & Providing advisory services through mass media & 85 & 70.83 & 35 & 29.17 \\
\hline 8 & Providing facilities for storage of farm produce & 65 & 54.16 & 55 & 45.84 \\
\hline 9 & $\begin{array}{l}\text { Ensuring remunerative price for agricultural } \\
\text { produce }\end{array}$ & 77 & 64.16 & 43 & 35.84 \\
\hline 10 & $\begin{array}{l}\text { Create awareness about government schemes on } \\
\text { marketing of agricultural produce }\end{array}$ & 63 & 52.50 & 57 & 47.50 \\
\hline 11 & $\begin{array}{l}\text { Ensure correct weighment and packing of farm } \\
\text { produce }\end{array}$ & 90 & 75.00 & 30 & 25.00 \\
\hline 12 & $\begin{array}{l}\text { Linking of credit with marketing of farm } \\
\text { produce }\end{array}$ & 41 & 34.17 & 79 & 65.83 \\
\hline 13 & $\begin{array}{l}\text { Prevention of unauthorized deduction of produce } \\
\text { by commission agents during sale of produce }\end{array}$ & 94 & 78.33 & 26 & 21.67 \\
\hline 14 & $\begin{array}{l}\text { Illegal deduction of commission by commission } \\
\text { agents }\end{array}$ & 87 & 72.50 & 33 & 27.50 \\
\hline
\end{tabular}

$* \mathrm{~F}=$ Frequency,$\%=$ Percentage 
Table.3 Socio-economic characteristics of farmers

\begin{tabular}{|c|c|c|c|}
\hline & & & $\mathrm{n}=120$ \\
\hline Sl. No. & Particulars & Frequency & Per cent \\
\hline \multirow[t]{4}{*}{1} & \multicolumn{3}{|l|}{ Age (years) } \\
\hline & Young $(\leq 36)$ & 24 & 20.00 \\
\hline & Middle (37-46) & 63 & 52.50 \\
\hline & Old $(\geq 47)$ & 33 & 27.50 \\
\hline \multirow[t]{7}{*}{2} & \multicolumn{3}{|l|}{ Education } \\
\hline & Illiterate & 15 & 12.50 \\
\hline & Primary School & 17 & 14.60 \\
\hline & Middle School & 09 & 07.50 \\
\hline & High School & 37 & 30.41 \\
\hline & Pre-University & 25 & 20.83 \\
\hline & Degree \& Above & 17 & 14.16 \\
\hline \multirow[t]{5}{*}{3} & \multicolumn{3}{|l|}{ Farming Experience (years) } \\
\hline & Low $(\leq 14.51)$ & 42 & 35.00 \\
\hline & Medium (14.52-23.16) & 44 & 36.66 \\
\hline & $\operatorname{High}(\geq 23.17)$ & 34 & 28.34 \\
\hline & & Mean $=18.84$ & $\mathrm{SD}=10.18$ \\
\hline \multirow[t]{6}{*}{4} & \multicolumn{3}{|l|}{ Size of Land holding (acre) } \\
\hline & Marginal farmers (up to 2.50) & 11 & 09.10 \\
\hline & Small farmers $(2.51-5.00)$ & 45 & 36.50 \\
\hline & Semi-medium (5.01-10.00) & 44 & 34.60 \\
\hline & Medium farmers (10.01-25.00) & 21 & 16.50 \\
\hline & Large farmers (above 25.01) & 04 & 03.30 \\
\hline \multirow[t]{5}{*}{5} & \multicolumn{3}{|l|}{ Marketable surplus } \\
\hline & Low $(\leq 83.53)$ & 30 & 25.00 \\
\hline & Medium (83.54-91.34) & 40 & 33.33 \\
\hline & High $(\geq 91.35)$ & 50 & 41.67 \\
\hline & & Mean $=87.44$ & $\mathrm{SD}=9.50$ \\
\hline \multirow[t]{5}{*}{6} & \multicolumn{3}{|l|}{ Marketed surplus } \\
\hline & Low $(\leq 78.22)$ & 33 & 27.50 \\
\hline & Medium (78.23-86.67) & 34 & 28.33 \\
\hline & High $(\geq 86.68)$ & 53 & 44.17 \\
\hline & & Mean $=82.45$ & SD $=9.96$ \\
\hline
\end{tabular}


Table.4 Relationship between socio-economic characteristic with role perception of farmers towards extension activities of APMC markets

\begin{tabular}{|c|l|c|}
\hline Sl. No. & Variables & Correlation coefficient (r) \\
\hline $\mathbf{1}$ & Age & 0.085 \\
\hline $\mathbf{2}$ & Education & $0.250^{*}$ \\
\hline $\mathbf{3}$ & Farming experience & 0.065 \\
\hline $\mathbf{4}$ & Land holding & 0.001 \\
\hline $\mathbf{5}$ & Information seeking behavior & -0.062 \\
\hline $\mathbf{6}$ & Cropping pattern & 0.134 \\
\hline $\mathbf{7}$ & Marketable surplus & -0.094 \\
\hline $\mathbf{8}$ & Marketed surplus & -0.098 \\
\hline $\mathbf{9}$ & Economic orientation & $0.259^{* *}$ \\
\hline $\mathbf{1 0}$ & Scientific orientation & $0.244^{* *}$ \\
\hline $\mathbf{1 1}$ & Risk orientation & -0.172 \\
\hline $\mathbf{1 2}$ & Contact with APMC market & $0.040^{*}$ \\
\hline ** Correlation is significant at the 0.01 level & \\
\hline *orrelation is significant at the $\mathbf{0 . 0 5}$ level & \\
\hline
\end{tabular}

It is found that more than forty per cent (41.67\%) of farmers had high marketable surplus followed by 33.33 and 25.00 per cent of medium and low marketable surplus respectively. It is found that 44.17 per cent had high marketed surplus followed by 28.33 and 27.50 per cent of medium and high marketed surplus. The reason might be that as there are more number of small farmers and semi-medium farmers they face the situation of distress sale as they might not be having capital to overcome operational cost. Nearly half of the respondents $(49.17 \%)$ had medium contact with APMC market followed by 31.67 and 19.17 per cent had low and high contact with APMC. Majority of the farmers are growing different types of crops in different seasons, in order to market the produce the farmers have to visit the APMC market frequently and avail the facilities.

It was observed in Table 4, that the variables economic orientation $(r=0.259)$ and scientific orientation $(\mathrm{r}=0.244)$ has positive relationship with role perception about extension activities at one percent level of significance and the variables education $(r=0.250)$ and contact with
APMC ( $\mathrm{r}=0.040)$ had positive relationship with role perception about extension activities of APMC market at five percent level of significance. The variables such as age $(\mathrm{r}=0.85)$, farming experience $(\mathrm{r}=0.065)$, land holding $(\mathrm{r}=0.001)$ and cropping pattern $(\mathrm{r}=0.134)$ had no significant relationship with role perception about extension activities. Whereas, the variables such as Information seeking behavior ( $\mathrm{r}=-0.062)$, marketable surplus ( $\mathrm{r}=-0.094)$, marketed surplus ( $\mathrm{r}=-$ $0.098)$ and risk orientation $(\mathrm{r}=-0.172)$ had negative co-relationship with role perception about extension activities. The possible reasons for the independent variables having significant relationship with role perception of farmers about extension activities are given in ensuring paragraphs.

In conclusion, around 60.00 per cent of farmers had perceived about the role 'ensuring transparency in trading that takes place in market area' and 40.00 per cent of them had not perceived about the role of APMC market. Regarding the role 'ensuring immediate payment to farmers' 67.50 per cent had perceived and 32.50 per cent had not 
perceived about the role. It was suggested that systematic efforts on the part of APMC required conducting the awareness activities among the farmers regarding reforms in regulated markets and role to be played by APMC and their personnel in extension activities.

\section{References}

Balappa S. R. and Hugar, L. B., 2003, An economic evaluation of onion production and its marketing system in Karnataka. Agricultural Marketing 46(2): 22-26.

Reddy, B.S. 1997, Production, Marketing and Processing of Redgram in Gulbarga district-An Economic Analysis. M.Sc. (Agri) Thesis University of Agricultural Sciences, Dharwad.

Dixit, A. K., Singh, M.K., Roy, A.K., Reddy, B. S. and Narendra Singh, 2015, Trends and contribution of grazing resources to livestock in different states of India. Range Management and Agroforestry. 36 (2): 204-210.

Goudappa S.B., Reddy B. S. and Chandrashekhar, S.M., 2012, Farmers perception and awareness of crop insurance in Karnataka. Indian Research Journal of Extension Education. 12 (Spl.iss.Vol-II): 218-222.

Hugar, L. B., Balappa Shivaraya and Yeriswamy, j., 2001, Dynamics of consumer behaviour in vegetable marketing. Indian Journal of Marketing,
31(9-10):27-33.

Joshi, G. R., 2014, Farmers satisfaction towards performance of APMC. EPRA International Journal of Economic and Business Review 2(8): 111-117.

Ramesh Safare., 2017, Role of market yard infrastructure facilities on agricultural producers: A case study of Kurnool market yard. International Journal of Managerial Studies and Research, 3(9): 137-141.

Sangappa Rampure., 2014, Perception about marketing management of APMC in Gulbarga Division. International Journal of Statistical Research, 3(12): 52-54.

Singh, L. P., 1993, Regulated markets in 21st century: an outline of their future role. Bihar Journal of Agricultural Marketing, 1(1): 7-13.

Shashidhara, K.K., 2017, A study on farmer's perception on ill effects of agro chemicals in north eastern part of Karnataka, Journal of Applied and Natural Sciences. 9 (4): 2158 - 2164.

Vijaya Kumara, R, Ramakrishna Gundu and Venkatesh Panasa., 2017, A study on farmers perception regarding various price sources and effectiveness of price utilization, awareness of APMC act in Telangana and constraints faced by farmers in marketing of various commodities. International Journal of Pure and Applied Biosciences, 5(5): 1108-1112.

\section{How to cite this article:}

Chandan, M. N., K. K. Shashidhara, B. S. Reddy and Goudappa, S. B. 2020. Perception of Farmers towards APMC Markets in Raichur District of Karnataka, India. Int.J.Curr.Microbiol.App.Sci. 9(07): 3704-3711. doi: https://doi.org/10.20546/ijcmas.2020.907.434 